attention was drawn to it by the fact that some of the arsenicated beers of Bacup were made from malt and hops only, no glucose or invert sugar being used. The brewers and analysts concerned were puszled to account for $i t$. The amount present was probably less than one grain of arsenic in 280,000 . One brewer found that $I$ had taken the first draw from the pump in the morning and suggested that the pipes and indiarubber tubing leading from the pumps to the barrel might be the cause. Samples of beer were taken from the wood or barrel and they were found to be absolutely free from arsenic by the most delicate tests known. It was clear, therefore, that the contamination must be after the beer left the barrel. I obtained a new pipe of the kind used in the trade and found arsenic present. I then obtained indiarubber tubing which had been used; arsenic was present in much larger quantity.

As regards the main cause of this arsenical poisoning epidemic, it is obvious that the amount of arsenic present in the rubber tubing used would not be of very serious account, as it is probably less than one part in 280,000 ; nevertheless, one can easily understand that beer having stood in the tubing all night, or for some considerable period, may be distinctly marred from this source. By Gubzeit's test there was distinct evidence of arsenic being present in both new and old indiarubber tubing, also in old and new lead piping. The old rabber tubing having been dissected into three layers, each was submitted separately to this test, also the layers together, and the resultis were compared. In old rubber tubing (1) the inner coat showed an appreciabie quantity of arsenic easily detected (the beer passing in to the tube was found to be arsenicated); (2) the middle coat or canvas layer gave the most marked result, arsenic being present in distinct quantity; and (3) the outer coat showed a very faint, almost inappreciable, quantity. On comparing the canvas layer or middle coat with the result of the three layers together it was quite clear that this coat was the most highly charged. New rubber tubing analysed similarly gave the following results: (1) the inner coat was practically free; (2) the middle coat again gave evidence of arsenic being present in somewhat similar quantities to those found in the old tubing ; and (3) the outer coat gave distinct traces. On comparing the canvas coat with the three layers together the results again showed the middle coat to be the chief source of arsenic. The quantity used in the above investigations was one gramme.

I am, Sirs, yours faithfully,

Bacup, Dec. 19th, 1900. JoHN BRown, M.D., D.P.H. Vict.

\section{ARSENIC AND AERATED WATERS.}

To the Editors of THE LANCET.

SIRs,-I referred in my communication to you re arsenic in beer ${ }^{1}$ as to the possibility of aerated waters prepared from arseniated sulphuric acid being contaminated. I am now glad to be able to report that no trace of arsenic could be found after exhaustive analysis in specimens of soda water, hop ale, and lemonade submitted for examination, although an impure specimen of sulphuric acid had been used in their manufacture. A very faint trace of lead was found in the lemonade, probably derived from the citric acid used. I may add that the impure sulphuric acid was at once returned to the manufacturers.

I am, Sirs, yours faithfully, A. H. BAMPTON, M.D. R.U.I.

Ilkley-in-Wharfedale, Dec. 15th, 1900.

\section{"A RECENT DEVELOPMENT IN ADVERTISING." \\ To the Editors of THE LANCEN.}

SIRS,-First let me thank you for the excellent advertisement you have given to Craigside Hydro, Llandudno, free of charge, in your leaderette in the issue of THE LANCET of Dec. 15 th, under the above heading. In the leaderette you have thought it necessary to condemn the method of advertising adopted by its directors, which method you describe as "evil," and moreaver charge medical men who take advantage of the directors' invitation with sacrifice of self-respect.

I cannot help feeling that you have made these charges with a very slight knowledge of what you write about, probably without seeing the letter accompanying the coupon.

1 The LaNCerr, Dec. 8th, 1900, p. 1675.
I cannot think that you object to a hydropathic establishment advertising, otherwise you would not admit advertisements of bydros to your advertisement columns. Nor can I think that you object to directors of such institutions bringing their establishment to the notice of the medical profession, otherwise the raison d'être for your advertisement pages is abolished. I conclude, therefore that it is the suggestion that medical men should at the cost (in some cases considerable) of their railway fare only be invited to visit the establishment to which they are asked to entrust their patients for, it may be, a considerable time.

I enclose a copy of the letter which accompanied the coupon and from this you will see that it is a straightforward request to medical men to send their patients to this establishment. It would be unreasonable to expect a doctor to send a patient to an establishment with which he was unacquainted; surely, therefore, the fact that he may once in his lifetime visit it for three days free of charge to satisfy himself that it is a suitable place to which a patient may be sent can scarcely involve such charges as the delicately hinted "bribery" and "corruption" and badly expressed "loss of self-respect" which you make in your article. I should like to draw attention to the following sentence: "It says in effect "We will pay you for a three days' holiday here, afterwards send your patients who will pay us." " Owing to your lack of knowledge of facts I hope, and not to a desire to "score" by innuendo, you have missed the object of the letter. You should have said : "It says, in fact, 'Come and stay for three days without charge, and if you find things as you wish send your patients who will pay us, as we consider our establishment suitable for patients whom you wish to send to the seaside."

I am pleased to say that your prognosis as to the manner in which the advertisement would be received by the profession has already proved incorrect, as the directors bave received numerous letters from doctors thanking them for the invitation and expressing the intention of the writers to avail themselves of the same, and have, moreover, cashed a considerable number of the coupons. It may be news to you, but it is nevertheless the fact, that it is not by any means an uncommon occurrence for medical men who write applying for charges for a holiday at a hydropathic establishment to ask for a reduction of terms in consequence of their profession and of their ability to recommend patients. As I said before, I enclose you the coupon and letter and trust you will be able to avail yourself of the directors' invitation.

$$
\text { I am, Sirs, yours faithfully, }
$$

Llandudno, Dec. 16th, 1900.

\section{J. MILES CHAMBERS,} Managing Director.

\section{To the Editors of THE LANCET.}

SIRS, - I write in the interests of mere justice (for I have no other interest in the matter) to protest against the tone of your annotation concerning the above. I for one can see no objection to the offer of entertaining medical men for three days in order to let them practically experience what manner of establishment is open for the reception of their patients if they please to recommend it. It is in no sense a constructive bribe, for no testimonial or quid pro quo is sought. If the medical man thinks the place worthy he can send his patients there-not unless. I have received advertisements from other establishments offering commission for sending patients, which is certainly objectionable; and from others offering to receive patients recommended by oneself at reduced charges, which might be open to abuse. But to the Craigside practice I cannot discern any honest objection. It is a perfectly fair and legitimate means of advertising -and without advertising how can such establishments become widely known? It is a guarantee to the public of the genuineness of the advantages of the establishment to submit it to such a practical test. To characterise it as an implied bribe to medical men is to lay the profession open to a most unworthy aspersion.

I am, Sirs, yours faithfully,

C. E. RICHMOND, F.R.C.S. Eng.

Manchester, Dec. 18th, 1900.

\section{"NEW-LAID EGGS AND FRESH EGGS."}

\section{To the Editors of THE LANOET.}

SIRS,-In THE LANCE'T of Dec. 15th, p. 1758, I was pleased to read in the letter of Sir W. T. Gairdner 